\title{
Simultaneous Determination of Copper, Iron and Nickel by High-Performance Liquid Chromatography after Preconcentration with Extraction and Back-Extraction
}

\author{
Yoshio Shijo, Nobuo Uehara, Tamotsu Kudo and Sachiko Aratake \\ Department of Applied Chemistry, Faculty of Engineering, Utsunomiya University, \\ Ishii-cho, Utsumomiya 321, Japan
}

Keywords Preconcentration, copper, iron, nickel, high-performance liquid chromatography, extraction, back-extraction, 2-(5-bromo-2-pyridylazo)-5-( $N$-propyl- $N$-sulfopropylamino)phenol, trioctylmethylammonium chloride

2-(5-Bromo-2-pyridylazo)-5-( $N$-propyl- $N$-sulfopropylamino)phenol (5-Br-PAPS) is one of the most useful spectrophotometric reagents ${ }^{1}$ for transition metals in pyridylazo compounds. In connection with the HPLC of metal complexes, 5-Br-PAPS is also excellent as a chelating agent owing to the sensitivity and thermodynamic stability of its complexes of metals, such as $\mathrm{V}$, $\mathrm{Cr}, \mathrm{Fe}, \mathrm{Co}, \mathrm{Ni}$ and $\mathrm{Cu}$. Therefore, 5-Br-PAPS has been extensively used for the separation and determination of metal ions by HPLC. Several papers concerning the determination of metal ions as their 5-Br-PAPS complexes by HPLC have been published. ${ }^{2-9}$ In these studies, separation was conducted almost exclusively with the use of RPHPLC by precolumn complexation, except for one postcolumn complexation. ${ }^{9}$ In order to increase the practical value of the HPLC determination of metals as their 5-Br-PAPS complexes, the most appropriate preconcentration method should be developed.

In this work, an extraction and back-extraction method for the 5-Br-PAPS complexes of $\mathrm{Cu}, \mathrm{Fe}$ and $\mathrm{Ni}$ was investigated with the aims to attain a higher concentration factor and to increase the injection volume of the extracts into RPHPLC. This method is based on the extraction of 5-Br-PAPS complexes with trioctylmethylammonium chloride (Capriquat) in xylene, followed by backextraction into a perchloric acid solution and subsequent separation by RPHPLC after neutralization of the back-extracts with a sodium acetate solution. In the proposed method, a concentration factor of up to about 130 and an injection volume of $50 \mu \mathrm{l}$ can be attained.

\section{Experimental}

\section{Apparatus}

HPLC separations were performed using a modular system comprising a Hitachi (Tokyo, Japan) L-6000 pump, a Hitachi L-4200 UV-VIS spectrophotometric detector, a Rheodyne (Cotati, CA, USA) 7125 loop injector, and a Hitachi D-2500 Chromatointegrator. A Merck (Darmstadt, Germany) LiChrosorb RP-18 (250 $\mathrm{mm} \times 4 \mathrm{~mm}$ i.d., particle size $7 \mu \mathrm{m}$ ) was used for all of the experiments. The $\mathrm{pH}$ measurements were made with a Hitachi-Horiba (Kyoto, Japan) F-7ss pH-meter.

\section{Reagents}

Stock solutions $\left(1000 \mathrm{mg} \mathrm{l}^{-1}\right)$ of $\mathrm{Cu}, \mathrm{Fe}$ and $\mathrm{Ni}$ were of atomic-absorption standard (Wako, Osaka, Japan) grade. A $5 \times 10^{-3} \mathrm{moll}^{-1} 5$-Br-PAPS solution was prepared by dissolving the requisite amount of 5-Br-PAPS (Dojin, Kumamoto, Japan) in water. A $5 \times 10^{-2} \mathrm{~mol} \mathrm{l}^{-1}$ Capriquat-xylene solution was prepared by dissolving the requisite amount of Capriquat (Dojin, Kumamoto, Japan) in xylene. Analytical reagent-grade methanol was purified by distillation. Water was purified with a Milli-Q system after distillation-deionization. All other chemicals used were of analytical reagent grade.

The mobile phase was methanol-water $(65 / 35 \mathrm{v} / \mathrm{v})$ containing $5 \times 10^{-5} \mathrm{~mol} \mathrm{l}^{-1} 5$-Br-PAPS, $0.1 \mathrm{~mol} \mathrm{l}^{-1}$ lithium chloride and $1 \times 10^{-2} \mathrm{~mol} \mathrm{l}^{-1}$ ammonium acetate buffer (pH 3.5). All of the chromatographic mobile phases used were filtered through $0.45-\mu \mathrm{m}$ filters. The flow rate was $0.60 \mathrm{ml} \mathrm{min}^{-1}$ and the detector was operated at $575 \mathrm{~nm}$.

\section{Procedure}

One milliliter of a $5 \times 10^{-3} \mathrm{~mol}^{-1} 5$-Br-PAPS solution was added to a known volume of an acidic sample solution containing $\mathrm{Cu}, \mathrm{Fe}$ and $\mathrm{Ni}$. After adjusting the pH to 4.5 by adding a $2 \mathrm{~mol}^{-1}$ sodium acetate solution, the mixture was diluted to $50 \mathrm{ml}$ with water. The solution was transferred into a separating funnel and $3 \mathrm{ml}$ of $5 \times 10^{-2} \mathrm{~mol} \mathrm{l}^{-1}$ Capriquat-xylene was added. The 5Br-PAPS complexes of the metals were extracted into xylene by shaking for $10 \mathrm{~min}$. After centrifuging, a $2 \mathrm{ml}$ aliquot of the organic phase was transferred into another centrifuge tube. The back-extraction of the complexes was carried out using $0.3 \mathrm{ml}$ of $1.7 \mathrm{~mol}^{-1}$ perchloric acid 
for $5 \mathrm{~min}$, after which the mixture was centrifuged for $2 \mathrm{~min}$. To a $0.2 \mathrm{ml}$ aliquot of aqueous phase, a $0.2 \mathrm{ml}$ of $2.2 \mathrm{~mol} \mathrm{l}^{-1}$ sodium acetate solution and a $0.1 \mathrm{ml}$ of methanol were added; then, $20 \mu \mathrm{l}$ of the mixture was injected into the HPLC.

\section{Results and Discussion}

\section{HPLC separation}

The 5-Br-PAPS complexes of various metals such as $\mathrm{Bi}, \mathrm{Co}, \mathrm{Cr}, \mathrm{Cu}, \mathrm{Fe}, \mathrm{Ni}, \mathrm{Pd}, \mathrm{Pt}, \mathrm{Rh}$ and $\mathrm{V}$ have been separated on an ODS column using methanol-water as the mobile phase..$^{2-4}$ In this work, similar HPLC conditions as those used in a previous study ${ }^{2}$ were used to separate the 5-Br-PAPS complexes of $\mathrm{Cu}, \mathrm{Fe}$ and $\mathrm{Ni}$ because the aim of this work was to investigate a preconcentration method for the HPLC of metal complexes. These complexes are selectively separated by HPLC from other metal ions.

\section{Extraction and back-extraction of $\mathrm{Cu}, \mathrm{Fe}$ and $\mathrm{Ni}$}

The effect of the $\mathrm{pH}$ on the extraction of $\mathrm{Cu}, \mathrm{Fe}$ and $\mathrm{Ni}$ was studied by using $50 \mathrm{ml}$ of an aqueous phase spiked with $0.4 \mu \mathrm{g}$ of each metal. The 5-Br-PAPS complexes extracted were back-extracted with perchloric acid into the aqueous phase with subsequent determination by HPLC. The results are shown in Fig. 1. The optimum $\mathrm{pH}$ ranges for the extraction are $4-6$ for $\mathrm{Cu}, 4-5$ for $\mathrm{Fe}$ and 4-5.3 for Ni. For subsequent work, the extraction was carried out at $\mathrm{pH} 4.5$.

Capriquat, which is a hydrophobic quaternary ammonium salt, is useful for the ion-pair extraction of most anionic complexes. From Fig. 2 it is evident that the constant peak areas of the complexes on the extraction are obtained with the Capriquat concentrations in xylene of above $4 \times 10^{-3} \mathrm{~mol}^{-1}$ for $\mathrm{Cu}$, and above $2 \times 10^{-3} \mathrm{~mol} \mathrm{l}^{-1}$ for $\mathrm{Fe}$ and $\mathrm{Ni}$.

The 5-Br-PAPS complexes of $\mathrm{Cu}, \mathrm{Fe}$ and $\mathrm{Ni}$ extracted with Capriquat are back-extracted into the aqueous phase using a hydrophobic anion, such as perchloric acid. The constant peak areas of the complexes on the backextraction are obtained at perchloric acid concentrations of above $0.5 \mathrm{~mol} \mathrm{l}^{-1}$ for $\mathrm{Cu}$ and $\mathrm{Fe}$, and above $1.5 \mathrm{~mol} \mathrm{l}^{-1}$ for $\mathrm{Ni}$. In subsequent work, $1.7 \mathrm{~mol} \mathrm{l}^{-1}$ perchloric acid was used for back-extraction.

The influence of the volume ratios of the aqueous-toorganic phase on the extraction and back-extraction of $\mathrm{Cu}, \mathrm{Fe}$ and $\mathrm{Ni}$ were studied. The results indicate that the extraction and back-extraction should be carried out with a volume ratio of the aqueous-to-organic phase of $<33: 1$ for the extraction and $>1: 10$ for the backextraction. A concentration factor for these metals from water of about 130-fold can consequently be achieved by a combined single extraction and backextraction.

\section{Calibration curves, detection limits and precision}

The peak-area calibration curves obtained according

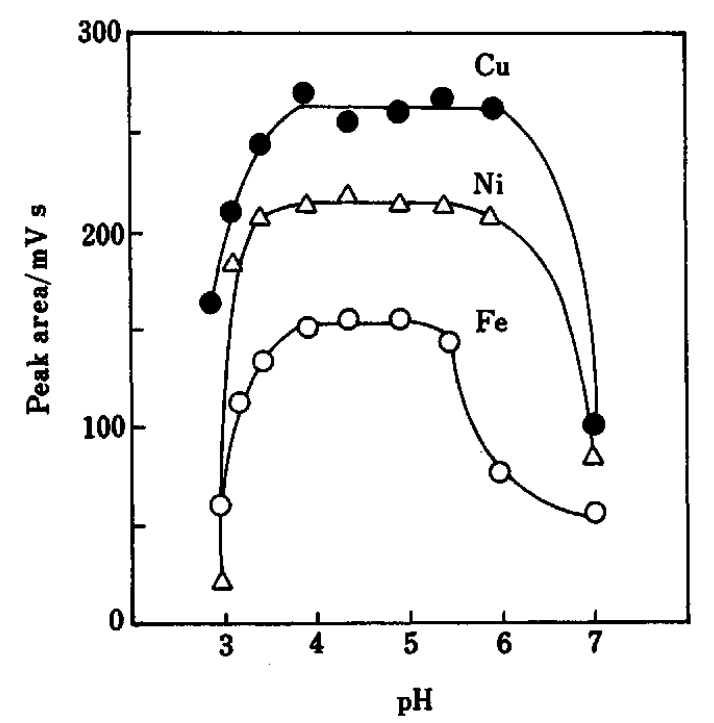

Fig. 1 Effect of $\mathrm{pH}$ on the extraction of $\mathrm{Cu}, \mathrm{Fe}$ and $\mathrm{Ni}$. 5Br-PAPS, $2.5 \times 10^{-5} \mathrm{moll}^{-1}$; Capriquat, $5 \times 10^{-2} \mathrm{~mol} \mathrm{l}^{-1}$; perchloric acid, $1.7 \mathrm{~mol} \mathrm{l}^{-1}$; aqueous phase, $50 \mathrm{ml}$; organic phase, $3 \mathrm{ml}$; final solution back-extracted, $0.5 \mathrm{ml}$.

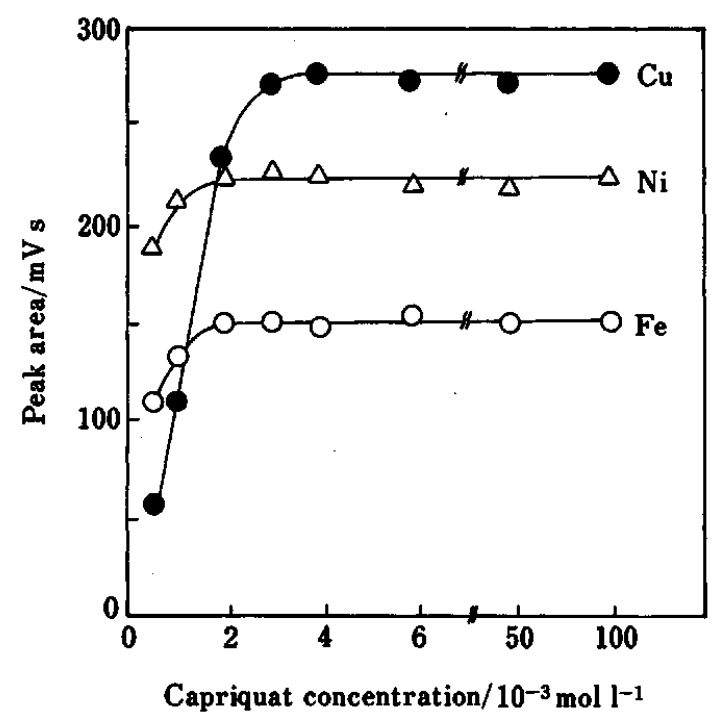

Fig. 2 Effect of the Capriquat concentration on the extraction of $\mathrm{Cu}, \mathrm{Fe}$ and $\mathrm{Ni}$. The $\mathrm{pH}$ was 4.5; all other conditions were as given in Fig. 1, except for the Capriquat concentration.

to the procedure described above were linear over concentration range of $0.4-20 \mu \mathrm{g} \mathrm{l}^{-1}$ for $\mathrm{Cu}, \mathrm{Ni}$ and $1-$ $20 \mu \mathrm{g} \mathrm{l}^{-1}$ for $\mathrm{Fe}$. The detection limits (signal-to-noise ratio of 3) were $0.15 \mu \mathrm{g} \mathrm{l}^{-1}$ for $\mathrm{Cu}, 0.55 \mu \mathrm{g} \mathrm{l}^{-1}$ for $\mathrm{Fe}$ and $0.46 \mu \mathrm{g} \mathrm{l}^{-1}$ for Ni. The relative standard deviations for a metal-ion concentration of $8 \mu \mathrm{g} \mathrm{l}^{-1}$ were $1.0 \%$ for $\mathrm{Cu}$, $2.0 \%$ for $\mathrm{Fe}$ and $2.4 \%$ for $\mathrm{Ni}$. 


\section{References}

1. T. Makino, M. Saito, D. Horiguchi and K. Kina, Clin. Chim. Acta, 120, 127 (1982).

2. Y. Shijo and K. Sakai, J. Chromatogr., 333, 133 (1985).

3. N. Uehara, Y. Annoh, T. Shimizu and Y. Shijo, Anal. Sci., 5, 111 (1989).

4. Y. Shijo and T. Shimizu, Analyst [London], 113, 1201 (1988).

5. N. Uehara, K. Morimoto, T. Shimizu and Y. Shijo, Chem.
Lett., $1989,411$.

6. C. Ohtsuka, H. Wada, T. Ishizuki and G. Nakagawa, Anal. Chim. Acta, 223, 339 (1989).

7. C. Ohtsuka, K. Matsuzawa, H. Wada and G. Nakagawa, Anal. Chim. Acta, 252, 181 (1991).

8. C. Ohtsuka, K. Matsuzawa, H. Wada and G. Nakagawa, Anal. Chim. Acta, 256, 91 (1992).

9. M. Saito, H. Tanzawa and T. Yamane, Mem. Fac. Lib. Arts Educ., Part 2 (Yamanashi Univ.), 42, 32 (1991).

(Received June 30, 1994) (Accepted September 14, 1994) 